\title{
Cortisol dynamics and endothelin-1/nitric oxide ratio are associated with clinical vasospasm
}

\author{
Julius July, ${ }^{1}$ Yesaya Yunus, ${ }^{1}$ Veli Sungono, ${ }^{2}$ Suryani As 'ad, ${ }^{3}$ Budhianto Suhadi, ${ }^{4}$ Andi A. Islam ${ }^{5}$ \\ ${ }^{1}$ Department of Surgery, Medical Faculty of Pelita Harapan University, Neuroscience Centre Siloam Hospital Lippo Village \\ Tangerang, Indonesia \\ ${ }^{2}$ Department of Public Health, Medical Faculty of Pelita Harapan University, Tangerang, Indonesia \\ ${ }^{3}$ Department of Clinical Nutrition, Medical Faculty of Hasanuddin University, Makassar, Indonesia \\ ${ }^{4}$ Department of Clinical Pathology, Medical Faculty of Pelita Harapan University, Tangerang, Indonesia \\ ${ }^{5}$ Department of Neurosurgery Medical Faculty of Hasanuddin University, Makassar, Indonesia
}

\begin{abstract}
Abstrak
Latar belakang: Dinamika kortisol serum mungkin berhubungan dengan vasospasme klinis, dikenal juga dengan delayed ischemic neurological deficits (DIND). Dua senyawa vasoaktif yang berperan dalam patofisiologi DIND adalah endotelin-1 (ET1) dan nitrit oksida (NO), keduanya dipengaruhi oleh kortisol. Penelitian ini bertujuan untuk mencari hubungan kortisol terhadap rasio ET1/NO dan hubungannya dengan DIND.
\end{abstract}

Metode: Penelitian ini merupakan studi kohort selama 14 hari pertama setelah perdarahan subaraknoid karena aneurisma (SAH). Pasien-pasien yang memenuhi kriteria inklusi diambil darahnya sebelum operasi dan pascaoperasi hari ke-2,4,7, dan 10 (antara jam 08.00-09.00 WIB). Pemeriksaan darah mencakup kortisol, ACTH, CBG, NO, ET1. Kortisol bebas dihitung dengan persamaan Coolens. Analisis regresi logistik digunakan untuk menilai hubungan antara kortisol total, kortisol bebas, NO, ET1, dan DIND. Analisis korelasi digunakan untuk menilai korelasi kortisol dan kortisol bebas dengan lama perawatan di rumah sakit.

Hasil: Terdapat 44 pasien dalam penelitian ini (20 pria, 24 wanita). Rerata usia 52,02 $\pm 11,23$ tahun. Terdapat perbedaan rerata kadar kortisol yang bermakna antara kelompok DIND $(35,99 \pm 14,24) \mu \mathrm{g} /$ dL dengan tidak DIND $(19,57 \pm 6,19)$ $\mu \mathrm{g} / \mathrm{dL}$ dengan nilai $p<0,001$. Demikian juga dengan kortisol bebas antara kelompok DIND $(2,06 \pm 1,094) \mu \mathrm{g} / \mathrm{dL}$ ditemukan perbedaan yang bermakna dengan kelompok tidak DIND $(0,838 \pm 0,365) \mu \mathrm{g} /$ dL dengan nilai $p<0,001$. Grafik Scattered plot korelasi kortisol terhadap rasio ET1/NO mulai terlihat meningkat pada hari ke-4 dan menjadi semakin kuat pada hari ke-10.

Kesimpulan: Kortisol berhubungan dengan DIND setelah perdarahan subaraknoid karena aneurisma, kemungkinan melalui peranannya terhadap keseimbangan kadar ET1 dan NO. (Med J Indones. 2013;22:161-6. doi: 10.13181/mji. v22i3.585)

\begin{abstract}
Background: Cortisol dynamics in serum might be related to clinical vasospasm, also known as delayed ischemic neurological deficits (DIND). Two vasoactive substances that play a role in pathophysiology of DIND are endothelin-1 (ET1) and nitric oxide (NO), both are proved associated with cortisol. This study aimed to know how cortisol plays a role on ET1/NO ratio and its relationship to DIND.
\end{abstract}

Methods: This was a prospective cohort study for the first 14 days after aneurysmal subarachnoid hemorrhage (SAH). Patients with inclusion criteria will be enrolled for blood test before surgery, and post-operative day 2, 4, 7, and 10 (between 8:00-9:00 AM). The blood tests were performed for cortisol, ACTH, CBG, NO, and ET1. Free cortisol is calculated with Coolens equation. Logistic regression was used to see the interaction model and its scale. Bivariate analysis (corelation) was used to see the relationship between total cortisol, free cortisol, NO, ET1, and clinical vasospasm (DIND).

Results: Forty-four patients were enrolled into this study (20 males; 24 females). Mean age was $52.02 \pm 11.23$ years. There were 29 patients $(66 \%)$ within DIND group and 15 patients non-DIND as the control group. The mean of cortisol level shown was significantly higher in DIND group $(35.99 \pm 14.24) \mu \mathrm{g} / \mathrm{dL}$ compared to non-DIND group $(19.57 \pm 6.19)$ $\mu \mathrm{g} / \mathrm{dL}, \mathrm{p}<0.001$. The mean of free cortisol level was significantly higher in DIND group $(2.06 \pm 1.094) \mu \mathrm{g} / \mathrm{dL}$ compared to non-DIND group $(0.838 \pm 0.365 \mu \mathrm{g} / \mathrm{dL} ; \mathrm{p}<0.001)$. The scatter plot graph showed that correlation of cortisol with ET1/NO ratio started increasing on day 4 and became stronger on day 10.

Conclusion: Cortisol is associated with DIND following aneurysmal SAH, probably through its role in keeping the balance between ET1 and NO level. (Med J Indones. 2013;22:161-6. doi: 10.13181/mji.v22i3.585)

Keywords: Cortisol dynamics, delayed ischemic neurological deficits, endothelin-1, nitric oxide

Cortisol dynamics in serum following subarachnoid hemorrhage (SAH) might be related to clinical vasospasm, also known as delayed ischemic neurological deficits (DIND). ${ }^{1} \quad$ Subarachnoid hemorrhage due to aneurysm rupture produces a highly stressful condition to the patient. Such stressful condition might stimulate the production and release of cortisol. 
Two important vasoactive substances that play a role in physiology and pathophysiology of DIND are endothelin 1 (ET1) and nitric oxide (NO). ${ }^{2}$ Endothelin 1 is produced by vascular smooth muscle cells and endothelial cells. It is a strong vasocontrictor that play antagonist role to $\mathrm{NO}$ as a vasodilator. ${ }^{3}$ Animal and cell culture studies have shown that glucocorticoid (cortisol) stimulate the production and release of ET1, probably through increase transcription of prepro-ET mRNA.., 5

Cortisol also inhibit the NO synthase (NOS), inducible NOS (iNOS) and endothelial NO (eNOS) isoforms, ${ }^{6,7}$ directly through reducing its production, ${ }^{8}$ or indirectly through reducing tetrahydrobiopterin as an essential co-factor of eNOS. ${ }^{9}$ This study aimed to observe the relationship between cortisol dynamic and ET1/NO ratio which might be associated with DIND.

\section{METHODS}

\section{Study design}

This was a prospective cohort study for the first 14 days after aneurysmal SAH. The study was conducted at Siloam Hospital Lippo village from January 2009 to December 2011. This study was designed to observe the cortisol dynamics in relation to the ET1/ NO ratio and its relationship with the disease course of aneurismal SAH. The study follows a consecutive cohort of aneurysmal SAH patients, age $>18$ years, who underwent clipping surgery within 72 hours of onset, and they were followed for 14 days. The exclusion criteria were glucocorticoid medication during admission or treatment, sepsis, and pregnancy. Patients who died on first post-operative day, were also excluded.

\section{Patient population and clinical data collection}

Demographic data including age, sex, and smoking behaviour were collected. All patients or their next of kin provided consent for this study, which is approved by the institutional Review Board of Universitas Hasanuddin Makassar (Registered Number: UH10080162). All patients underwent CT-angiography to identify the aneurysm location, and to reduce the bias, only patients who underwent clipping surgery were enrolled. All patients were managed in the intensive care unit by the neurosurgical and neurointensivist team. Nimodipine was routinely given for at least 14 days (with infusion rate of $2 \mathrm{mg}$ /hour). Lumbal drain was also routinely inserted to drain the blood stained CSF. The neurological status was assessed at the time of admission and graded according to World Federation of Neurosurgical Society (WFNS) Scale. ${ }^{10}$ CT-scan grading according to Fisher ${ }^{11}$ were also recorded. Clinical vasospasm also known as DIND is defined as a decrease Glasgow coma scale (GCS) more than one point compare to initial assessment. Patients, outcome was graded according to modified Ranklin scale ${ }^{12}$ at the time when the patients went home.

\section{Laboratory study}

Patients with inclusion criteria will be enrolled for blood test before surgery, and post-operative day 2 , 4, 7, and 10. A ten milliliter sample of venous blood was taken between 8.00-9.00 AM every scheduled day. All serum and plasma were stored at $-80^{\circ} \mathrm{C}$ until completion of the study. The blood study consist of cortisol, adrenocorticotrophic hormone (ACTH), cortisol-binding globulin (CBG), NO, and ET1. Serum cortisols levels $(\mu \mathrm{g} / \mathrm{dL})$ were measured with an immunoassay using Elecsys cortisol kit (cat no 11875116 122). Cortisol binding globulin levels $(\mu \mathrm{g} / \mathrm{mL})$ were measured with radio immunoassay using transcortin RIA (cat no MG13061). Reference interval for male $22-55 \mu \mathrm{g} / \mathrm{mL}$ and female $40-154$ $\mu \mathrm{g} / \mathrm{mL}$. Free cortisol is calculated with Coolens equation. ${ }^{13}$ ACTH levels $(\mathrm{pg} / \mathrm{mL})$ were measured with an immunoassay using ALPCO immunoassay (cat 21-ACTHU-E01, lot 1391). NO level (pg/dL) were measured with photometric assay measurement, using Nitrate/ Nitrite Colorimetric Assay Kit (cat No.780001) from Cayman Chemical Co. US. ET1 level $(\mathrm{pg} / \mathrm{dL})$ were measured with quantitative enzyme immunoassay technique, using assay designs stressen bioreagents (catalog No.900-020A).

\section{Statistical analysis}

All the data were analyzed using SPSSv16, (SPSS Inc., Chicago, IL) and reviewed by a professional statistical consultant. Data were presented descriptively and underwent bivariate analysis. Comparison analysis (Independent t-test) was used to see the difference of total cortisol, free cortisol, ET1, and NO between DIND group and Non DIND group during the onset of DIND. Corelation analysis and logistic regression analysis is used to see the relationship, interaction model and it's scale between total cortisol, free cortisol, ET1, NO, and DIND neurological status.

\section{RESULTS}

There were 44 patients enrolled in this study (20 male; 24 female). Mean age is 52.02 years $(52.02 \pm 11.23)$. 
Initially, $38(86 \%)$ patients came with WFNS grade 3 or better, and $33(75 \%)$ patients presented with Fisher grade 3 or less. Most of the cases, 18 (41\%) were presented on day one of ruptured aneurysm, 15 $(34 \%)$ on day two, dan $11(25 \%)$ on day 3 . There were 46 aneurysms, two patients have 2 aneurysms each. Most aneurysms, $43(93 \%)$ are located at anterior circulation.

There are 29 patients $(66 \%)$ on DIND group and 15 (44\%) of Non DIND group. Age distribution between the two groups are not significantly different $(p=0.224)$. The mean of cortisol $(p<0.001)$ and free cortisol $(p<$ 0.001 ) during the onset of DIND is significantly higher compared to the Non DIND group (Table 1).

Logistic regression result shows a significant relationship between free cortisol and DIND $(\mathrm{p}=0.005)$. The odds ratio is 34.19 (high), conversion to risk become $97 \%$. Unfortunately the $95 \%$ CI range is very wide (2.95396.32). Although the statistical result showed significant association of free cortisol with DIND outcome ( $\mathrm{p}=$ 0.005 and odds ratio/OR 34.19 ); the $95 \% \mathrm{CI}$ is very wide (2.95-396.32). This wider confidence interval means the more variability of this sample population with lowest point estimation of $\mathrm{OR}=2.95$ and the highest point estimation OR $=396.32$ ), but all of the OR are more than 1 which means there is a significant association. The total cortisol level also shows significant association with DIND ( $\mathrm{p}=0.001)$. Although its OR is small (1.21), but the $95 \% \mathrm{CI}$ is narrow (1.07- 1.37) and its standard deviation is 0.074 (Table 2). It means that the results show more consistency of association, with a lower limit of 1.07 and a higher limit of 1.37 .

There is no statistical difference in terms of mean of length of stay between the two groups $(p=0.057)$ (Table1), but if we observe carefully the result support that patient with DIND will have longer hospital stay
(Table 3).The cortisol and free cortisol on day $-2,-4$, -7 , and -10 showed significant correlation with length of stay in hospital $(\mathrm{p}<0.05)$ (Table 3$)$.

The role of cortisol on ET1/NO ratio started to show significancy on day 4 , and became stronger and stronger in the second week (Figure 1).

Patients' outcomes based on modified Ranklin Scale were fairly good, only two cases of mortality occured. One died on day 15 due to progressive vasospasm, and another one died on day 16 due to pneumonia.

Table 2. Logistic regression result between cortisol, free cortisol, ACTH, CBG with DIND

\begin{tabular}{lccc}
\hline Indicator & $\mathrm{p}$ & $\mathrm{OR}$ & $95 \% \mathrm{CI}$ \\
\hline Cortisol & 0.001 & 1.21 & $1.07 ; 1.37$ \\
Free-Cortisol & 0.005 & 34.19 & $2.95 ; 396.32$ \\
CBG & 0.081 & 0.95 & $0.89 ; 1.00$ \\
ACTH & 0.844 & 1 & $0.98 ; 1.02$ \\
ET1/NO ratio & 0.314 & 0.98 & $0.95 ; 1.01$ \\
\hline
\end{tabular}

Table 3. Correlation between cortisol and free cortisol with length of stay

\begin{tabular}{rcclc}
\hline \multirow{2}{*}{ Day } & \multicolumn{2}{c}{ Cortisol } & \multicolumn{2}{c}{ Free cortisol } \\
\cline { 2 - 5 } & $\mathrm{r}$ & $\mathrm{p}$ & $\mathrm{r}$ & $\mathrm{p}$ \\
\hline Day 0 & 0.155 & 0.328 & 0.205 & 0.194 \\
Day 2 & 0.319 & 0.045 & 0.515 & 0.001 \\
Day 4 & 0.360 & 0.019 & 0.339 & 0.028 \\
Day 7 & 0.315 & 0.042 & 0.318 & 0.040 \\
Day 10 & 0.371 & 0.018 & 0.252 & 0.117 \\
\hline
\end{tabular}

Table 1. Comparison of mean cortisol, free cortisol, and other variables between non DIND group and DIND group

\begin{tabular}{llllll}
\hline \multirow{2}{*}{ Variable } & \multicolumn{2}{c}{ Non DIND $(\mathrm{n}=15)$} & \multicolumn{2}{c}{ DIND $(\mathrm{n}=29)$} & $\mathrm{p}$ \\
\cline { 2 - 5 } & Mean $\pm \mathrm{SD}$ & Min/Max & Mean $\pm \mathrm{SD}$ & Min/Max & \\
\hline Cortisol $(\mu \mathrm{g} / \mathrm{dL})$ & $19.57 \pm 6.19$ & $8.30 / 30.84$ & $35.99 \pm 14.24$ & $15.73 / 70.12$ & $<0.001$ \\
Free cortisol $(\mu \mathrm{g} / \mathrm{dL})$ & $0.84 \pm 0.37$ & $0.23 / 1.54$ & $2.06 \pm 1.09$ & $0.65 / 4.25$ & $<0.001$ \\
ACTH $(\mu \mathrm{g} / \mathrm{dL})$ & $30.02 \pm 25.39$ & $8.14 / 96.44$ & $31.90 \pm 33.12$ & $3.22 / 128.06$ & 0.849 \\
CBG $(\mu \mathrm{g} / \mathrm{dL})$ & $39.99 \pm 11.86$ & $18.44 / 60.80$ & $33.41 \pm 11.05$ & $14.00 / 56.50$ & 0.075 \\
ET1/NO ratio $(\mathrm{pg} / \mathrm{dL})$ & $0.36 \pm 0.15$ & $0.19 / 0.73$ & $0.43 \pm 0.31$ & $0.03 / 1.38$ & 0.394 \\
Age $($ year $)$ & $49.00 \pm 8.67$ & $36.00 / 64.00$ & $53.00 \pm 12.21$ & $22.00 / 74.00$ & 0.224 \\
Length of stay (day) & $22.00 \pm 17.05$ & $10.00 / 69.00$ & $42.00 \pm 39.27$ & $11.00 / 215.00$ & 0.057 \\
\hline
\end{tabular}



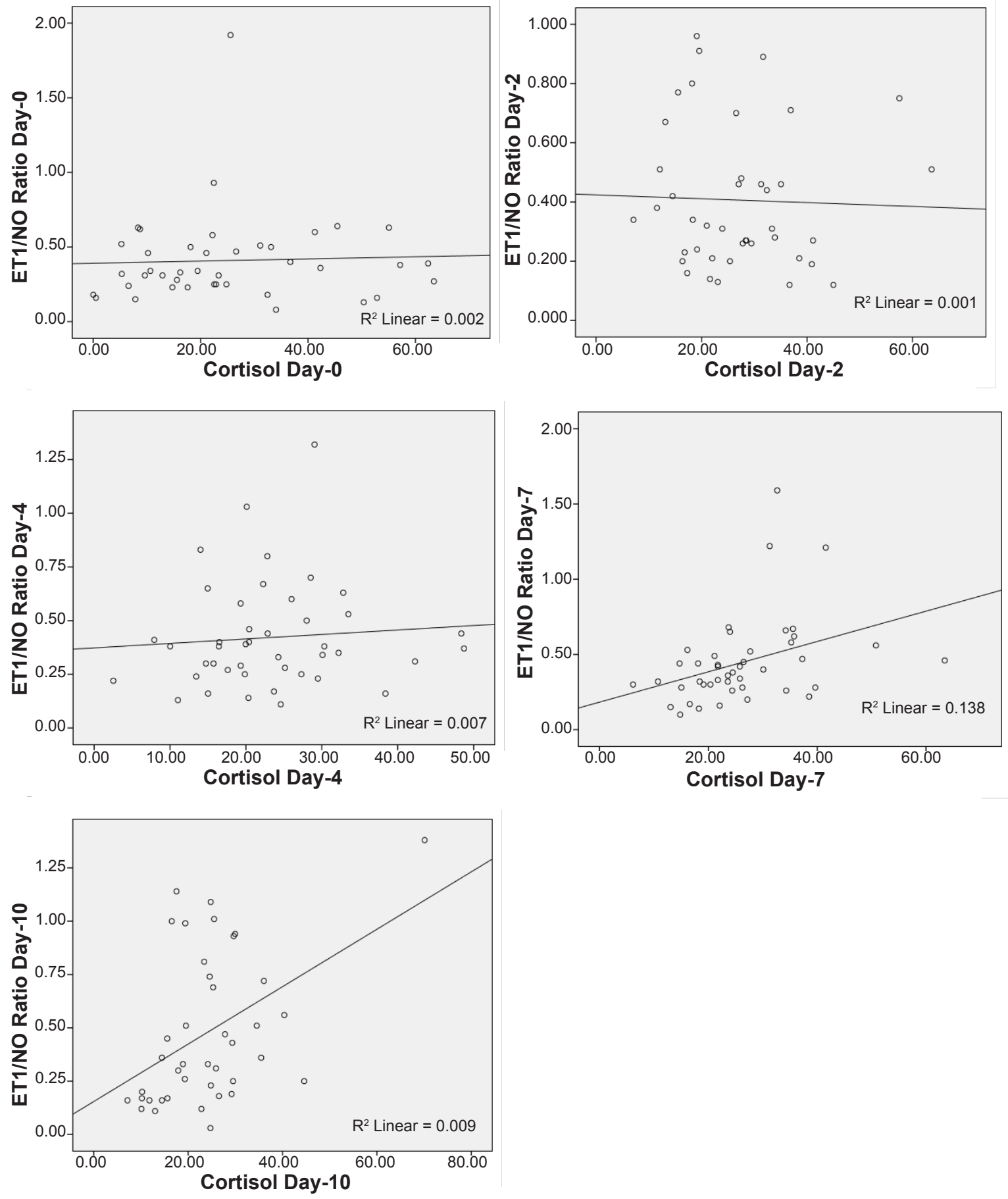

Figure 1. Scattered plot graph shows correlation between cortisol and ET1/NO ratio on day 0,2,4,7 and 10

\section{DISCUSSION}

The role of cortisol after aneurysmal SAH is still unclear. SAH after the aneurysm rupture produces a very stressful condition to the patient. ${ }^{14}$ The blood that occupied the subarachnoid space cause a severe headache (thunderclamp headache) and it also iritate all the neurovascular structure especially the hypothalamus pituitary area. Such condition might stimulate the production and release of cortisol. Recent studies support the evidence that patient with SAH suffered severe systemic stress, including the cardiovascular system. ${ }^{15}$ Previous study have shown that cortisol dynamics in the acute phase of aneurismal SAH is associated with disease severity and outcome. ${ }^{1}$ Study by Bendel, et al which evaluate the pituitary-adrenal function after acute subarachnoid hemorrhage showed that the severity of disease was not associated with cortisol level. ${ }^{16}$ In their study, they did not look at the correlation between cortisol and neurological state. Also they failed to show 
the differences of adrenal response between comatous $(\mathrm{GCS}<8)$ and non comatous patients.

Our study, showed that there are significant differences for both cortisol level $(p<0.001)$ and free cortisol level ( $p$ $<0.001$ ) between the DIND group and non DIND group (Tabel 3). Vergouwen, et al also showed that increase in cortisol level was associated with DIND, probably through hyperglicemia and endothelial dysfunction (von Willebrand factor). ${ }^{17}$ The von Willebrand factor is synthesized by, and stored in, endothelial cells. When it's released, this factor appears to mediate platelet aggregation and adhesion.

Cortisol release during the first week of SAH is predominantly controlled by the hipothalamo-pituitaryadrenal axis through ACTH. At the second week, its role is taken over extra ACTH cortisol release. ${ }^{14}$ It's probably due to the inflamation pathway that become dominant after the first week. It involves interleukin-6 (IL-6), ${ }^{18} \mathrm{IL}-1$, and TNF- $\alpha .{ }^{19}$

Whether the role of the cortisol is part of stress response or it also contribute to the clinical worsening of DIND is still unclear. The result on free cortisol that significantly increased during the onset of DIND $(p<0.001)$ support the evidence that it probably play some biological role during the clinical worsening. Serum cortisol have been proven to associate with increased vasoconstriction response of coronary vessels. ${ }^{20}$ Similar process might happen to brain blood vessels after aneurysmal SAH. Cortisol stimulate the production and release of ET1 through increased transcription of prepro-ET mRNA. ${ }^{4}$ It also inhibit NOS, iNOS, and eNOS isoforms, ${ }^{7}$ directly through reducing its production ${ }^{8}$ and indirectly through reducing production of essential cofactor of eNOS, the tetrahydrobiopterin. ${ }^{9}$

Result of this study shows that the role of cortisol on ET1/NO ratio started at day-4 and became stronger at the second week. It is consistent with the evidence that DIND usually start at day-3 or -4 following $\mathrm{SAH}$, progressively worsening until day-7 when the oxyhemoglobin level from blood degradation product reached its peak level. ${ }^{21}$

It is concluded that high cortisol level is associated with DIND following aneurysmal SAH. The role of cortisol probably is through its role on maintaining the balance between ET1 and NO level.

\section{REFERENCES}

1. Poll EM, Bostrom A, Burgel U, et al. Cortisol dynamics in the acute phase of aneurysmal subarachnoid hemorrhage: associated with disease severity and outcome. J Neurotrauma. 2010;27(1):189-95.
2. Suhardja A. Mechanism of disease: Roles of nitric oxide and endothelin -1 in delayed cerebral vasospasm produced by aneurismal subarachnoid hemorrhage. Nature Clinical Practice Cardiovascular Medicine. 2004;1(2):110-6.

3. Bourque SL, Davidge ST, Adams MA. The interaction between endothelin -1 and nitric oxide in the vasculature: new perspectives. AmJ Physiol Regul Integr Comp Physiol. 2011;300(6):R1288-95.

4. Morin C, Asselin C, Boudreau F, Provencher PH. Transcriptional regulation of pre-pro-endothelin-1 gene by glucocorticoids in vascular smooth muscle cells. Biochem Biophys Res Commun. 1998;244(2):583-7.

5. Provencher PH, Villeneuve A, Morin C. Glucocorticoids increase preproendothelin-1 expression in rat aorta. Endocr Res.1998;24:737-41.

6. Korhonen R, Lahti A, Hamalainen M, Kankaanranta H, Moilanen E. Dexamethasone inhibits inducible nitricoxide synthase expression and nitric oxide production by destabilizing mRNA in lipopolysaccharide-treated macrophages. Mol Pharmacol. 2002;62(3):698-704.

7. Wallerath T, Witte K, Schafer SC, et al. Down-regulation of the expression of endothelial NO synthase is likely to contribute to glucocorticoid-mediated hypertension. Proc Natl Acad Sci U S A. 1999;96(23):13357-62.

8. Rogers KM, Bonar CA, Estrella JL, Yang S. Inhibitory effect of glucocorticoid on coronary artery endothelial function. Am J Physiol Heart Circ Physiol. 2002;283(5):H1922-8.

9. Thony B, Auerbach G, Blau N. Tetrahydrobipterin biosynthesis, regeneration, and functions. Biochem J. 2000;347:1-26.

10. Drake CG. Report of World Federation of Neurological Surgeons Committee on a universal subarachnoid hemorrhage grading scale. J Neurosurg. 1988;68(6):985-6.

11. Fisher CM, Kistler JP, Davis JM. Relation of cerebral vasospasm to subarachnoid hemorrhage visualized y CT Scanning. Neurosurgery. 1980;6(1):1-9.

12. Van Swieten JC, Koudstaal PJ, Visser MC, Schouten HJA, van Gijr J. Interobserver agreement for the assessment of handicap in stroke patients. Stroke. 1988;19(5):604-7.

13. Coolens JL, Van BH, Heyns W. Clinical use of unbound plasma cortisol as calculated from total cortisol and corticosteroid-binding Globulin. J Steroid Biochem. 1987;26(2):197-202.

14. July J, As'ad S, Suhadi B, Islam AA. The association between cortisol dynamics and the course of aneurysmal subarachnoid hemorrhage. Asian J Neurosurg. 2011;6(2):83-7.

15. July J, As'ad S, Suhadi FX, Islam AA. Cortisol dynamics are associated with electrocardiographic abnormalities following the aneurysmal subarachnoid hemorrhage. J Cardiovasc Dis Re. 2012;3(4):315-8.

16. Bendel S, Koivisto T, Ruokonen E, et al. Pituitary-Adrenal function in patients with acute subarachnoid haemorrhage; A prospective cohort study. Crit Care. 2008;12:R126.

17. Vergouwen MD, van Geloven N, de Haan RJ, Kruyt ND, Vermeulen M, Roos YB. Increased cortisol levels are associated with delayed cerebral ischemia after aneurysmal subarachnoid hemorrhage. Neurocrit Care. 2010;12(3):342-5. 
18. Sarrafzadeh A, Schlenk F, Gericke C, Vajkoczy P. Relevance of cerebral interleukin- 6 after aneurysmal subarachnoid hemorrhage. Neurocrit Care. 2010;13(3):339-46.

19. Hanafy KA, Grobelny B, Fernandez L, et al. Brain interstitial fluid TNF-alpha after subarachnoid hemorrhage. J Neurol Sci. 2010;291(1-2):69-73.

20. Hizume T, Morikawa K, Takaki A, et al. Sustained elevation of serum Cortisol level causes sensitization of coronary vasoconstricting responses in pigs in vivo: A possible link between stress and coronary vasospasm. Circ Res. 2006;99(7):767-75.

21. Pluta RM, Afshar JK, Boock RJ, Oldfield EH. Temporal changes in perivascular concentrations of oxyhemoglobin, deoxyhemoglobin, and methemoglobin after subarachnoid hemorrhage. J Neurosurg. 1998;88(3):557-61. 